\title{
A BIPOLARIDADE POLÍTICA RIO-GRANDENSE \\ E O MOVIMENTO OPERÁRIO (188?-1925)
}

Adhemar Lourenço da Silva Jr. ${ }^{1}$

O bipartidarismo da cultura política rio-grandense - variável na análise de quase qualquer fenômeno da República Velha - diferenciava-o de outros estados no período, não só devido à necessidade constante de um discurso legitimador por parte do Partido Republicano (PRR), como também pelo alto grau de ideologização dos partidos. É difícil precisar se a ideologização precedia ou não a formação dos partidos, mas as interpretações correntes (estribadas em Trindade, 1979) a apontam como efeito, devido à tendência da oposição política (os "federalistas") de incorporar ao seu campo todas as propostas divergentes do castilhismo-borgismo, de forte inspiração comtista, que servia de esteio ao PRR.

No entanto, o bipartidarismo - ou melhor, a bipolaridade política - não parece ter papel relevante nas análises feitas sobre o movimento

Mestre em História-UFRGS; professor da UFPel. Dedico este artigo a meu pai, que nunca soube ficar em cima do muro. 
No entanto, o bipartidarismo - ou melhor, a bipolaridade política - não parece ter papel relevante nas análises feitas sobre o movimento operário da República Velha. ${ }^{2}$ Creio que para isso contribui a percepção de que a disputa entre republicanos e federalistas (e outros grupos de oposição) pertencia exclusivamente à "grande política" estadual, e apenas marginalmente afetava a "pequena política" das organizações operárias. De certa forma, a historiografia gaúcha se espelha na produzida em outros estados onde, de fato, as relações oligárquicas só conferiam um espaço mínimo à intervenção política da classe trabalhadora. Essa concepção da historiografia, eivada de um dever-ser da classe trabalhadora, bane de sua análise qualquer posição operária que venha em defesa dos partidos políticos de então, sob a (suposta) alegação de que não representariam sequer formas de consciência tradeunionista de classe (Batalha, 1990). Desse modo, os momentos de radicalização das disputas partidárias seriam apenas momentos privilegiados de desorganização no campo da "grande política", capazes de permitir a emergência pública de demandas operárias. O movimento operário, em contextos como o da Revolução Federalista (1893-1895), só seria marginalmente envolvido com tais disputas, por meio da "interpelação" pelos discursos em pugna (Rüdiger, 1991). De certo modo, a idéia de que o "paternalismo borgista" - evidenciado claramente na Greve Geral porto-alegrense de 1917 (Petersen, 1979) corresponderia igualmente a um discurso exógeno ao movimento operário partilha dessa mesma concepção, ao buscar investigar aquela que seria ou resultaria na "verdadeira" consciência de classe, nunca a "falsa", proveniente da burguesia ou da elite política.

Há, com efeito, certo grau de injustiça para com a historiografia, quando aponto para sua ignorância com respeito à bipolaridade política nas análises do movimento operário. Na verdade, como membros dessa cultura política, os historiadores gaúchos trataram da bipolaridade lançando mão de parte da tripolaridade presente no movimento operário de outros estados. As correntes políticas do movimento operário em outros estados seriam o socialismo, o anarquismo e os

2 Ao escrever minha dissertação de mestrado em 1994, essa afirmação era plenamente verdadeira. A crítica documental de Eliana Xerri (1996), no entanto, trabatha os efeitos da bipolaridade política nos registros de diferentes jornais sobre os conflitos de trabalho. O presente trabalho resulta da pesquisa efetuada para o mestrado, ao qual foram adicionadas informaçōes colhidas em investigaçāo financiada pela FAPERGS. 
"amarelos" (colaboracionistas). A bipolaridade no movimento operário do Rio Grande do Sul restringiria essas três correntes simplesmente a uma disputa entre anarquistas e socialistas, quase inexistindo referências, no período da República Velha, a associações operárias de tipo colaboracionista. No entanto, essa posição da historiografia ainda não trata sistematicamente da bipolaridade, por restringi-la somente às "ideologias" operárias. Com o presente texto, quero ressaltar a importância dessa variável na análise do movimento operário, considerando tanto a "grande política" estadual quanto a "pequena política" operária. Dizendo em outros termos, pretendo demonstrar que as disputas na "grande política" não apenas abrem espaço para a emergência de demandas operárias, mas garantem um espaço efetivo de negociação dessas demandas, com respeito ao qual se orientam as disputas no interior da "pequena política". ${ }^{3}$

\section{Antes de 1905}

O jornal socialista porto-alegrense Gazetinha, que circulou na década de 1890, já em 17 de abril de 1892 preocupava-se com as eleições que viriam, lamentando a incapacidade do operariado de eleger um "representante genuíno". A possibilidade de apoiar candidatos de outros partidos, não ligados organicamente às associações operárias, era descartada a partir da análise de outro caso, não nomeado nem localizado no tempo, em que o suposto representante operário traíra seus eleitores, trazendo "desilusão" à classe com o envolvimento na luta política de "ambiçôes e ódios". Antes ou depois da Revolução Federalista, não faltaram artigos desse teor, tentativas talvez ingênuas de compreender o momento em que viviam a partir da análise de momentos pretéritos da organização operária. Em 1896, tendo a Gazetinha já voltado a circular, um artigo publicado em 27 de setembro louva a organização da Liga Operária de Pelotas e da União Operária de Rio Grande, lamentando o fato de que, em Porto Alegre, a Liga Operária Internacional tivesse no máximo 200 sócios, "existindo po-

3 Esses comentários nāo se aplicariam aos estudos de Joan Bak (1994 e 1996), que analisam as associaçōes ferroviárias como exemplos de colaboracionismo, não com o patronato, mas com o Estado. Nesse tipo de análise, obviamente, a grande política acaba assumindo um importante papel. 
rém nas diferentes oficinas e fábricas [da capital] muito mais de 5.000 operários". Por que isso? Por que os operários de Porto Alegre tenderiam a descrer dos intentos de organização que se promoviam, invocando "questiúnculas" que só traziam o "desprestígio de tão grandiosa classe"?

Uma coluna específica do jornal empenhar-se-á, a partir de então, mais uma vez, na propaganda operária em Porto Alegre. E, já no primeiro artigo (22 nov. 1896), é aventada uma explicação: é que "a classe operária daqui (...) tem sido o gato morto de quase todos os partidos políticos". O artigo compara, sem encontrar grandes diferenças, dois momentos de envolvimento das organizações operárias com os partidos da grande política estadual: o primeiro, nebulosamente localizado antes da Proclamação da República, quando o Partido Liberal teria negociado um representante dos operários na Assembléia Provincial em troca do auxílio eleitoral. O "representante" era um industrial gasparista que "nunca disse (...) duas palavras sequer em defesa dos interesses daqueles de quem era o delegado", tendo votado inclusive contra tais interesses. Essa última atitude teria levado as organizações a planejarem a aplicação de uma "prova pública de reprovação", o que não ocorreu por ter o representante, temeroso, renunciado ao cargo. O segundo caso teria ocorrido em março de 1890 , quando Júlio de Castilhos acordara não só publicar no jornal governista A Federação as propostas do Partido Operário (Franco, 1988, p. 74), como também incorporaria à sua bancada para a Constituinte estadual um representante dos operários. João Steenhagen (Bak, 1994, p. 33), no entanto, não fez muita coisa em prol das associações operárias (clubes, escolas noturnas, associações beneficentes) que o apoiaram, isso por dois motivos: "era capitalista e correligionário entusiasta da maioria da Assembléia".

O ideário socialista do jornal e de seu articulista talvez não se sentisse à vontade com a história de seu representante "capitalista", mas o pior, segundo sua avaliação, era, realmente, seu pertencimento ao PRR, pois isso fez com que os operários organizados passassem a priorizar seu envolvimento com os partidos políticos: enquanto alguns passaram a apoiar a dissidência republicana (cassalistas), outros tor- 
naram-se federalistas, afora a "pequena parte [que] retirou-se descrente" dos intentos organizativos. ${ }^{4}$

Complexa era, nesse momento, a situação vivida pelos próceres da organização operária no Rio Grande do Sul. Mesmo que seu socialismo estivesse mais associado a uma postura moral - e mesmo não se opusesse ao anarquismo, como posteriormente se verificaria (Silva Jr, 1994, p. 129-33) -, ainda assim persistia a idéia que advogava a necessidade de construção de um partido político operário. Essa necessidade provinha menos da idéia de uma missão histórica da classe e mais da constatação da impossibilidade de constituição de uma burguesia industrial politicamente independente. A única "burguesia" existente no Rio Grande do Sul já era a elite política e se restringia, conforme artigo de 1893, à "burguesia da vaca" (Petersen \& Lucas, 1992, p. 52-56). Tal "burguesia da vaca", lutando entre si por ocasião da Revolução Federalista, embora expusesse fissuras capazes de permitir a eclosão de demandas públicas do movimento operário, obstava a constituição de uma terceira via partidária, vinculada, por exemplo, à II Internacional:

Os Estados onde nós contamos com o maior número de afiliados sâo: Ceará, Pará, São Paulo e Rio de Janeiro. No Rio Grande do Sul, de onde se esperava muito, o movimento está paralisado pela reação política dos partidos burgueses (Pinheiro \& Hall, 1979, p. 29).

Com a paz de 1895 , disputavam espaço no interior da "pequena política" duas propostas. A primeira julgava a constituição de um partido socialista de massas - a exemplo do Partido Social-Democrata Alemão - como pré-requisito para a ampliação do movimento operário. Tal partido teria uma função eminentemente pedagógica, ao catalisar os sentimentos humanitários para com a classe operária no campo da "grande política", o que permitiria o crescimento do número de afiliados das associações da "pequena política". A segunda proposta acreditava que o partido operário seria o resultado da organização e ampliação das associações de trabalhadores e que, portanto, era nelas prioritário investir. Embora as propostas aparentemente não delineas-

4 Caso semelhante parece ter ocorrido em Rio Grande. Em 1892 fundara-se a Liga Operária, que se dissolveu pelo fato de alguns operários "levarem a política desmoralizada da burguesia para o seio da classe” (Echo Operário, 24 out. 1897). Agradeço a Benito Bisso Schmidt pela indicação. 
sem grupos distintos na "pequena política", em torno delas debatiamse os rumos do movimento operário, como por exemplo quando da discussão sobre a organização de associações profissionais (diríamos hoje "sindicatos") a partir da Liga Operária Internacional de Porto Alegre. Enquanto os partidários da primeira proposta pensavam que era uma "idéia muito adiantada (...) a subdivisão das classes", pois era necessário "primeiramente ensinar a todos os companheiros a doutrina socialista", os partidários da segunda proposta julgavam que a organização de associações profissionais traria "ótimos resultados" (Gazetinha, 14 jan. 1897).

É difícil entender exatamente o que foi o partido socialista riograndense (sic, em minúsculas) fundado em maio de 1897: por um lado, contava com anarquistas em suas fileiras (Giuseppe Vitola e Giuseppe Ferla); por outro lado, chegou a concorrer nas eleições municipais de Rio Grande (Petersen \& Lucas, 1992, p. 89-104). O fato é que, em seu interior, debatiam-se as duas propostas, a que priorizava o partido e a que priorizava as organizações profissionais. Esse debate estaria presente no Congresso Operário Sul Rio-Grandense, de janeiro de 1898 , quando algumas lideranças propuseram a convocação de um congresso nacional e a fundação do Partido Socialista Brasileiro, propostas que foram rejeitadas por "inoportuna[s]" (Petersen \& Lucas, 1992, p. 108).

Após o Congresso, abriu-se uma cisão entre os socialistas, cujas causas não estão bem estabelecidas. Os que priorizavam o partido eram acusados de "mestres intelectuais dos operários [que] só têm sabido dar-lhes lições de vaidade e desorganização" (Echo Operário, 2 abr. 1899 apud Jardim, 1990, p. 68). Os que priorizavam as associações profissionais, congregados no "imaginário" Clube Socialista Carlos Marx, além de semearem “prevenções e ódios, desnecessários ainda entre capitalistas e operários”, fazendo, na verdade, contrapropaganda da organização, ainda tinham contra si várias máculas morais. A principal dessas máculas morais não era, contudo, o fato de serem ex-suicidas ou apontadores do jogo do bicho: era o envolvimento desses socialistas com a "grande política", pois eles seriam, na verdade, antigos cassalistas, que viriam a fazer na Liga Operária Internacional "a mesma campanha dissolvente que (...) [fizeram] na 
União Operária ou Centro Operário e no grêmio dramático Boêmios" (Gazetinha, $1^{\mathrm{o}}, 14$ e 24 nov. 1898). ${ }^{5}$

Após essa disputa, escasseiam os dados sobre a atividade operária em Porto Alegre, mas não os efeitos da bipolaridade política. O jornal socialista Avante!, publicado em 1901, já se inicia tomando posição sobre as disputas entre os socialistas de Porto Alegre: "Não é o brado de sugestôes partidárias e interesseiras, nem a grita dos velhos ódios políticos que se fará ouvir no jornal que hoje aparece...". Para vencer a disputa que fragilizara o movimento socialista, o jornal propunha o esquecimento da "grande política", o que tornaria viável a organização de associações profissionais politicamente neutras:

Considerando que a origem da ausência de muitos operários dos centros onde se luta não é devida somente à intriga dos interessados e interesseiros...

Considerando que só a luta econômica dentro das associações e a política num partido propriamente dos trabalhadores pode substituir a soberania personal por um regime de plena igualdade individual... (Reproduzido em Petersen, 1989, p. 1920).

\section{Anarquistas e socialistas (1905-1907)}

As cizânias internas parecem, com efeito, adormecidas nos primeiros anos do século XX. O jornal porto-alegrense A Democracia, ao mesmo tempo que propagandeava as atividades do Partido Operário Rio-Grandense, lamentava a inexistência das "sociedades operárias que ainda há pouco fulguravam entre nós com grande entusiasmo" (11 jun. 1905). Em sua edição de 9 julho, o mesmo jornal inventariava as sociedades existentes em Porto Alegre: além do Partido Operário, havia quatro profissionais (trabalhadores em madeira, padeiros, gráficos, metalúrgicos), uma de corte étnico (Allgemeiner Ar-

5 Os vínculos entre militantes operários e oposiçāo política no Rio Grande do Sul não estariam necessariamente relacionados a opções ideológicas, mas a opçōes políticas, como argumentaria Newton Stadler de Souza (1970, p. 130-139), quando observa que Colombo Leoni (diretor do jornal rio-grandense L'Avvenire) formou o Batalhāo Ítalo-brasileiro para lutar em favor dos federalistas no Paraná por causa da açăo legalista contra a Colônia Cecília. 
beiterverein), duas pluri-profissionais (União Operária Internacional, Confederação Obreira).

O jornal, publicado em 1905 e 1907 (em 1906, teve poucos números), não transige de sua posição em favor da independência política do operariado. Tece críticas abertas a diversos quadros do PRR (nas oficinas do A Federação, na administração da Casa de Correção), envolve-se em polêmica com o jovem Otávio Rocha, descrê da possibilidade de eleição de representantes operários, apesar de haver mobilizações nesse sentido (11 e 18 jun. e 24 set. 1905), critica o apoio de operários de São Gabriel ao candidato de oposição (26 maio 1907), assinalando ainda que, apesar da polarização entre Carlos Barbosa e Fernando Abbot nas eleições estaduais, nenhum dos dois melhoraria a situação do operariado (21 jul. 1907), desmentindo, ademais, que apoiava Abbot (19 maio 1907).

Se demarcássemos a posição política do jornal como favorável à independência política da classe e sua associação em entidades profissionais, estaríamos frente a apenas uma meia-verdade: prova sua relação com os anarquistas que se organizariam em 1906, por meio do jornal A Luta. A Democracia dizia não abrigar "propaganda anarquista” em suas páginas (19 nov. 1905), mas louvava Elisée Réclus ( 9 jul. e 22 out. 1905) e publicava textos de Domela Nieuwenhuis (21 abr. 1907), transcrevia e propagandeava a "folha radical" rio-grandina $O$ Proletário (1 out. e 12 nov. 1905), noticiava, parabenizando, atividades e decisões da União Operária Internacional - entidade na qual estavam anarquistas (9 jul. 1905) - e agradecia ao A Luta pelo envio do folheto "Bases do sindicalismo", já conhecido dos socialistas (13 jan. 1907).

Os anarquistas construíam sua posição no movimento operário a partir da proposta ("sindicalismo") de abandonar a luta pela inserção político-partidária no sistema eleitoral, priorizando a constituição de sociedades de resistência que mantivessem a neutralidade política e religiosa ("sindicatos"). A proposta não se contrapunha necessariamente à de parcelas dos socialistas: no sindicato se faria a luta econômica e, para que não se dispersasse a classe, essa associação deveria ser politicamente neutra. Era a posição necessária, segundo seus partidários, para que se mantivesse um mínimo de autonomia nas associações de trabalhadores. Conforme já apontei, quaisquer associações que se formassem tenderiam a ser absorvidas, ou pelo PRR, ou pelos federalistas e as declarações de neutralidade política dos grupos 
de interesses, como são os sindicatos, não seriam suficientes para evitar o engajamento político desses grupos, embora tais declarações sejam dos poucos instrumentos disponíveis para tanto. Desse modo, mesmo que os socialistas quisessem construir grandes associações de trabalhadores, com o objetivo de manter uma política autônoma de classe, as associações "socialistas" deveriam se declarar politicamente neutras. As relações das associações operárias com os grupos de orientação política - fossem socialistas ou anarquistas - eram informais: não são os sindicatos os que subscrevem programas de grupos políticos, mas as lideranças desses sindicatos. Esse seria o meio de tentar resguardar a neutralidade política das associações operárias.

Mas é também uma meia-verdade dizer que o único meio utilizado pelo A Luta para a construção de uma posição anarquista no movimento operário era a propaganda do sindicalismo. Ainda que o jornal não o diga exatamente, consta que o principal foco de atrito entre o A Luta e o A Democracia era o boato que os editores do primeiro teriam espalhado sobre a prisão de Antônio Nalepinski: acusavam os socialistas Carlos Cavaco e Francisco Xavier da Costa de denunciá-lo à polícia (A Democracia, 14 e 28 fev. 1907). A discussão entre ambos os jornais não estava pautada, portanto, sobre o mérito de diferentes formas de ação política, mas sobre critérios morais de conduta dos militantes. José Rey Gil, que já se contrapusera a Xavier da Costa na década de 1890 , a ele contrapõe-se novamente. Xavier da Costa defende-se publicando artigos danosos ao anarquismo, mas publica especialmente artigos danosos aos anarquistas de Porto Alegre, acusando-os de "canalhas, dominados pela inveja", pouco leais, caluniadores (14 fev. 1907), ignorantes, traidores e fazedores de intrigas (28 fev. 1907), burgueses, promotores de distúrbios e "parasitas da propaganda operária” (10 mar. 1907).

\section{O progressivo alinhamento dos socialistas com a grande política (1908-1912)}

Tais acusações sobre a conduta dos anarquistas tendem a desaparecer das páginas do A Democracia a partir de abril de 1907. Mas, aparentemente, a lógica da ação política operária não é de imediato percebida pelas lideranças socialistas. Em 7 julho 1907, inventariando a composição da Federação Operária (FORGS), o A Demo- 
cracia traz os nomes dos delegados da União dos Chapeleiros, dos Metalúrgicos, dos Trabalhadores em Madeira e do Grêmio de Artes Gráficas e Correlatas, além de trazer várias notícias louvando a organização da União dos Pedreiros. Os trabalhadores iam adotando a forma de organização sindical (não mais pluri-profissional), seguindo, por um lado, as propostas dos anarquistas, sem no entanto romper seus vínculos de lealdade para com as lideranças socialistas. ${ }^{6}$

$\mathrm{O}$ problema torna-se ainda mais complexo à medida que os socialistas tendem a tomar posição com relação às disputas da grande política. Se em 1907, quando das eleiçōes estaduais, os socialistas denunciavam republicanos e democratas, em 1908, quando das eleições municipais em Porto Alegre, o Partido Operário passaria a apoiar e integrar as "chapa popular", também chamada de "tríplice aliança" (federalistas, democratas e operários), lançando a candidatura do marceneiro Luiz Leopoldo Wetter ao Conselho Municipal. Dentro do próprio socialismo levantam-se vozes contra o acordo, denunciando a

"decepção por que hão de passar os operários que tendo seu partido vão se deixar embair [sic] iludir mais uma vez tropeçando no caminho tortuoso que lhes está preparado ao lado de federalistas e democratas. (...). É um absurdo, é um erro gravíssimo comprometedores [sic] da classe que não deve afastar-se da sua diretriz entrando em conchavo com agremiações das quais, mais cedo ou mais tarde, receberá o ludibrio como recompensa. (...) A classe operária (...) deve apresentar-se só, pleiteando a eleição, nunca fazendo cauda a coligaçōes que vêm de prejudicá-los" (Echo do Povo, 3 set. 1908).

Wetter não se elegeu, mas a disputa pelo controle dos votos operários passou a integrar as preocupações dos partidos da grande política. O coronel republicano Marcos de Andrade, controlador do PRR em Porto Alegre e imediações, teria procurado Xavier da Costa para falar-lhe do interesse de Borges de Medeiros em dar uma cadeira na Assembléia de Representantes para um operário. O Coronel Marcos preferia o nome de Xavier da Costa, que disse não aceitar a indicação,

6 São muitas as fontes deste item. Destaco especialmente os jornais Echo do Povo, A Luta, Correio do Povo e $O$ Exemplo do período tratado. Também foi consultada uma primeira versão da dissertação de Benito Bisso Schmidt, a quem agradeço as indicações sobre Rio Grande. Sobre as greves de pedreiros em 1911, v. Silva Jr., 1996 a. 
por querer submetê-la à Comissão Central do Partido (Echo do Povo, 12 mar. 1909). Um ano depois, o jornal A Luta (10 maio 1910) anunciava uma outra cisão entre os socialistas: Carlos Cavaco apoiava Rui Barbosa para a Presidência da República, enquanto Xavier da Costa apoiava, tal como o PRR, Hermes da Fonseca.

Enquanto os socialistas discutiam, dividindo-se entre posiçōes neutralistas, pró-republicanas e pró-federalistas, as organizaçôes profissionais tendiam a se desenvolver, sem alinhar-se com a grande política. Para o caso específico de Porto Alegre, a imprensa socialista, anarquista e popular traz várias informações sobre o andamento da organização profissional de pedreiros, metalúrgicos, trabalhadores em madeira, padeiros, chapeleiros, correeiros, pintores, estivadores, afora as notas sobre grupos de lazer e cultura operários (filodramáticos, bailantes e mesmo um "Centro Sportivo", dedicado especialmente ao futebol). Em Rio Grande, a Sociedade União Operária desde 1903 proibia aos associados a propaganda de partido político "dentro ou fora do recinto da sociedade em seu nome" e, em 1909, reformava seu estatuto no sentido de dar-lhe "o caráter de que carece como operária, progressista e livre pensadora para o que é preciso organizar as classes sob a forma sindicalista" (grifo meu).

Quatro eventos escandem e encerram o progressivo alinhamento dos socialistas com o PRR. O primeiro é uma greve derrotada na metalúrgica de Alberto Bins, em junho de 1910. Após a greve, Xavier da Costa, presidente da FORGS, renuncia ao cargo em favor do pedreiro Luiz Derivi, não deixando, porém, de promover reuniōes de aconselhamento com seus herdeiros políticos. Em 1911, ocorre uma greve vitoriosa de pedreiros em Porto Alegre, com repercussões em cidades como Bagé, Rio Grande e Pelotas. A novidade dessas greves e mobilizações é o papel de mediador exercido pelos intendentes municipais e por Carlos Barbosa, Presidente do Estado, inclusive concedendo a reivindicação de 8 horas de trabalho aos operários empregados em obras públicas e recebendo comissões de grevistas. Embora Luiz Derivi declarasse publicamente sua fidelidade pessoal a Xavier da Costa, a organização da greve dos pedreiros em Porto Alegre correspondia a ideais anarquistas de auto-organização, instituindo uma espécie de "comissão de fábrica" (aliás, "de obra") com funçôes deliberativas e executivas.

O terceiro evento é o alinhamento das associações de trabalhadores com as propostas anarquistas para a organização operária. É 
certo que a disputa de 1907 interferia na definição de rumos das associações operárias, mas, desde a entrada de Derivi na Federação Operária, a disputa esfumava-se. Em dezembro de 1910, os gráficos das duas correntes fundam a União Tipográfica. As eleições da FORGS em maio de 1911 são apontadas como exemplo do "chefismo caindo" (processo iniciado por Derivi), quando dois membros da União Operária Internacional ocupam cargos na diretoria. Em 1912, as escolas mantidas pela União dos Pedreiros e pela União Operária Internacional têm sua administração entregue à FORGS. Em maio de 1912, há uma disputa entre duas chapas: uma liderada por Luiz Derivi (apoiado pelos sindicalistas e/ou anarquistas) e outra liderada por Guilherme Koch (possivelmente apoiada pelos socialistas próximos a Xavier da Costa). A primeira é vitoriosa, não trazendo, contudo, muitas defecções à FORGS, isso porque, logo após a eleição de 1911, ocorreu o grande round dessa disputa (v. abaixo).

O quarto evento é a ascensão de Xavier da Costa ao cargo de conselheiro municipal (vereador) em 1912. O processo de aproximação do PRR, como vimos, já vinha de alguns anos antes: o Coronel Marcos já procurara os operários, Xavier da Costa já se declara hermista, a Intendência Municipal já doara um terreno nas imediações do Campo da Redenção para a construção do Ateneu Operário (cuja pedra fundamental fora lançada em maio de 1910) e os poderes públicos já haviam acedido à reivindicação de 8 horas para os pedreiros. Em 12 de outubro de 1911, uma carta-aberta solicita a Borges de Medeiros que indique um representante do operariado pelo PRR para a deputação estadual na Assembléia de Representantes. Tal candidatura "alcançaria a dupla vantagem de prestar bons e necessários serviços tanto à classe operária, como ao glorioso Partido Republicano." (Petersen \& Lucas, 1992, p. 162). Xavier da Costa não se tornou deputado, mas conselheiro municipal pelo PRR em 1912. Posteriormente, quando os sindicalistas se referiram à antiga diretoria da FORGS como aqueles que levavam o operariado a "chafurdar na política" (Petersen \& Lucas, 1992, p. 166), não estavam apenas denunciando equívocos políticos dos socialistas. Estavam denunciando a utilização da máquina coronelista - que em princípio excluía as demandas de setores populares - pelos que tentavam ser os representantes desses setores.

Esse quarto evento sela o destino político do socialismo, uma vez que abdicou da autonomia política da classe. É difícil dizer que a 
conduta dessa corrente resultou em ou resultou da abertura de espaço aos sindicalistas. $\mathrm{O}$ fato é que, nos anos seguintes, o sindicalismo não mais precisou temer a disputa com outras correntes.

\section{Os anos de expansão do sindicalismo: 1913-1917}

Quando dizia que o grande round da disputa entre sindicalistas e socialistas na FORGS ocorrera em 1911, referia-me à efetiva consolidação dos primeiros no movimento operário. Já em junho de 1911, a União dos Correeiros, a União dos Pintores e a dos Chapeleiros, entidades da órbita de Xavier da Costa, desligaram-se da Federação. Em setembro desse mesmo ano, Carlos Cavaco, junto com outros 34 militantes, funda a Confederação Geral do Trabalho, avaliando que "pedreiros, carpinteiros e empregados em estabelecimentos fabris" integrariam a nova associação. Equivocara-se Cavaco: integrar-se-iam à nova associação a União dos Correeiros, dos Trabalhadores em Madeira, dos Chapeleiros e a Towarzystvo Napzod (Sociedade Operária Polaca). Nesse mesmo mês de setembro, Francisco Xavier da Costa denuncia que a nova diretoria da Federação Operária promovera desfalques na associação, ao passo que fora acusado de não prestar contas dos fundos da greve de 1906. Xavier da Costa acusa criminalmente Henrique Martins de calúnia, vence o processo e o último foge para o Rio de Janeiro para não cumprir a pena de multa e prisão.

Xavier da Costa vence na justiça, mas os ânimos tendem a se acalmar. Em 1912, apesar de haver duas chapas para a eleição da diretoria da Federação Operária, não há registro de novas defecções de associações, afora aquelas que saíram em 1911. A ida de Henrique Martins para o Rio de Janeiro ativou os vínculos entre a nova diretoria da Federação Operária e os militantes do centro do país empenhados em reconstruir a Confederação Operária Brasileira. Com efeito, o Rio Grande do Sul foi o estado com o maior número de entidades representadas (19 delas aderidas à Federação Operária, 1 jornal de Bagé e 4 entidades aderidas à Federação Operária de Pelotas, perfazendo um total de 26 entidades) no II Congresso Operário Brasileiro de 1913, e manteve-se em uma posição eminentemente sindicalista, obtendo inclusive espaço de destaque nas páginas do jornal A Voz do Trabalhador entre os anos de 1913 e 1915 (Silva Jr., 1995a). 
Entre os anos de 1913 e 1917, as associações operárias fizeram greves, manifestações, lançaram jornais, o de sempre... Os sindicalistas não pareciam ameaçados por nenhuma outra posição política. Mesmo a fundação do Partido Socialista Riograndense, em 1914, não foi visto como algo mais que uma "patuscada". A neutralidade política das associações levou-as a protestar contra as cooperativas em 1913, mas não fê-las especialmente apoiar os governos municipal de Porto Alegre e estadual pelas medidas de controle das exportações de alimentos, fazendo-as ainda passar incólumes pela disputa entre Ramiro Barcellos e Hermes da Fonseca em 1915. Em Porto Alegre, greves de padeiros foram duramente reprimidas em 1914; greves de canteiros e calceteiros foram tratadas com certa condescendência em 1916. Se a atitude dos partidos da grande política não mais trazia cisões internas ao movimento operário, os militantes desarmavam-se para a luta interna. O jornal A Luta já deixara de circular em 1911 e a União Operária Internacional mantinha-se envolvida com escolas. Um relatório de militantes de meados de 1914 dizia que em Porto Alegre já não havia grupos anarquistas, outro dizia que em Pelotas havia um há pouco fundado, aparentemente com o objetivo de orientar os rumos políticos de associações também há pouco fundadas (A Vida, $31 \mathrm{dez}$. 1914; 28 fev. 1915).

\section{A conjuntura 1917-1918 e a "incorporação do proletariado"}

Em 1917, a deterioração das condições de vida e trabalho condicionou as grandes mobilizações que ocorreram em vários pontos do Brasil, inclusive em Porto Alegre, Pelotas e nas ferrovias do Rio Grande do Sul. Em Porto Alegre, a diretoria da FORGS, talvez por já haver esquecido disputas de anos anteriores, não dava mostras de ímpeto. Durante uma greve de canteiros e calceteiros em março desse ano (Silva Jr., 1995b), a Federação Operária limitou-se a promover comícios, sem declarar explicitamente seu apoio ao movimento, apenas solicitando que as entidades filiadas apoiassem aquela "causa justa", como já fizera em janeiro, por ocasião de uma greve de tecelóes. Em determinado momento, quando a Federação, como mediadora, recomendou ao Sindicato dos Canteiros suprimir determinada rei- 
vindicação da pauta, sequer foi atendida. ${ }^{7}$ Há indícios de que os cargos da diretoria da Federação Operária não eram então ocupados por anarquistas e que tais militantes eram inclusive contrários a uma greve geral. Anarquistas tentam "revigorar" a União Operária Internacional e é possível identificar seus membros protagonizando a criação da Liga de Defesa Popular, comitê diretor da greve geral que afetou Porto Alegre entre 31 de julho e 4 de agosto. Diferente das greves de categorias profissionais que abundam na historiografia, a pauta de reivindicação da greve geral em Porto Alegre dirigia-se especialmente ao poder público, versando sobre o preço de venda de produtos e serviços.

Os governos do estado e do município acedem a algumas reivindicaçỗes da Liga de Defesa Popular. Analisando-se a atitude do poder público frente às reivindicações da greve, vemos que algumas foram obtidas e postas em prática - as feiras livres, por exemplo. Mesmo as que não foram obtidas, vinham com justificativas e análises que justapunham as "condições prementes em que se encontra o proletariado" e as reivindicações da Liga de Defesa Popular, reconhecendo-a como um grupo de interesse legítimo para negociar com o Estado. Isso nos levaria a pensar a política do PRR (especialmente em nível municipal) à luz de dois tipos ideais de racionalidade política construídos por Claus Offe (1989). A racionalidade "conjuntural", mais afeita ao modelo liberal clássico, consideraria as demandas dos grupos de interesses (os sindicatos, por exemplo) como dadas, demandas que deveriam ser satisfeitas, desde que dentro dos limites orçamentários. Nessa situação, os órgãos do Estado e os partidos políticos poderiam negociar e propor soluções, pois o "bom" exercício dessa racionalidade política seria expresso pela "eficiência e a efetividade dos resultados". Em sentido contrário, viria uma racionalidade "estrutural", buscando manter as demandas em níveis "razoáveis ou suportáveis", devido à impossibilidade institucional ou orçamentária de satisfazê-las. Nesse caso, o "bom" exercício dessa racionalidade não é "satisfazer demandas, mas dar-lhes uma forma e canalizá-las de modo a torná-las possíveis de serem satisfeitas”. Mesmo contraditórias, tais racionalidades podem coexistir empiricamente e a tarefa do pesquisador seria a de ver como isso ocorre.

7 Estudo mais detalhado sobre a agitação operária em 1917 pode ser visto em Silva Jr., 1994 e $1996 b$. 
Embora possamos inicialmente concordar com Ângela de Castro Gomes (1979, p. 71 e ss.), analisando a política do PRR como mais afeita à do liberalismo clássico, há - em nível embrionário, é certo, mas nem por isso menos visível - um certo grau de reconhecimento, de atribuição de status institucional à Liga de Defesa Popular e à FORGS. As autoridades não se limitaram a "dar o exemplo" ao patronato, concedendo as 8 horas e o aumento salarial. O Chefe de Polícia e o Intendente Municipal não só mediaram negociaçóes, como "aconselharam" o patronato a ceder. A greve acabou não só porque houve ocupação militar da cidade, mas também porque o Chefe de Polícia "aconselhou" as lideranças operárias a ordenarem a extinção do movimento. Em suma, houve o reconhecimento, por parte do Estado, da legitimidade de um órgão como a Liga de Defesa Popular, pois é ela que encaminharia queixas, reclamações, petições, solicitações, representações, sugestốes etc. É ela que sugeria locais para os mercados livres e a periodicidade de seu funcionamento. É por causa desse embrião de status institucional que o Intendente se detém em justificativas do atendimento ou não de algumas reivindicações da greve.

A Liga de Defesa Popular aceita esse status, divulgando a legislação, sugerindo esta ou aquela correção na política pública, comparecendo à inauguração de feiras. Mas essa situação acarreta custos políticos, pois

... o grupo que possui status (...) deixa de ter suas açōes e realizaçōes exclusivamente determinadas pelos interesses, ideologias, percepçōes de necessidades etc. de seus membros, bem como pela força relativa que possui em relaçăo a outros grupos com os quais entra em competição ou aliança (Offe, 1989, p. 244).

Que custos foram esses? Como foram administrados no movimento operário de Porto Alegre? A Liga de Defesa Popular, criada sob a órbita dos anarquistas, passou a contar com representantes de todos os sindicatos da FORGS - inclusive os que não se envolveram com a preparação da Greve Geral - esvaziando os propósitos iniciais da primeira e transferindo-os à segunda. A FORGS, como grupo de interesse com status, fazia da apropriaçăo de cargos de direção na entidade mais do que a administração da federação a serviço de seus membros: seus diretores colocavam-se em posição privilegiada para a obtenção de benefícios pelos poderes públicos. A situação reforçava o peso dos não-anarquistas da FORGS, apoiados pelo edil republicano 
Francisco Xavier da Costa, que acenava com a possibilidade de obter certas medidas por via legal e mesmo subvencionava parte dos custos financeiros de manutenção da entidade, atribuindo-lhe, segundo a terminologia de Offe (1989) não só o já obtido status de reconhecimento, mas também o status de recursos, configurando uma tendência "corporativa". Ao reforço das posiçôes não-anarquistas, somava-se o descrédito em que caíram parte dos anarquistas da Liga de Defesa Popular de 1917, com a circulação do boato de que teriam sido subornados pelo alto comércio porto-alegrense para encerrar a Greve Geral (Gertz, 1989, p. 124-125).

Não parece correto atribuir ao PRR como um todo essa política de "incorporação do proletariado à sociedade moderna", tal como foi executada em Porto Alegre. As greves ferroviárias de julho e outubro de 1917 receberam apoios (às vezes vacilantes) de negociantes e de membros da oposição política, e não só do PRR: todos tinham motivos para apoiar os trabalhadores. O pragmatismo dos ferroviários os teria levado a tentar garantir a aliança de todas as correntes políticas, inclusive dando vivas ao "povo sem politicagem" (Bak, 1996, p. 17). Já em Pelotas, a greve geral, deflagrada em 8 de agosto, não encontra a mesma posição do PRR no governo municipal. Há tiroteios entre grevistas e a polícia municipal (um morto e vários feridos de parte a parte) e invasão da sede da Liga Operária. As forças da Brigada Militar, e o próprio Chefe de Polícia, deslocam-se para a cidade para tentar mediar as negociações, não só entre patrões e empregados, mas principalmente entre o Comitê de Defesa Popular e a Intendência Municipal. Esses dois exemplos atestam que a atribuição efetiva de status só ocorreu em Porto Alegre, não em Pelotas ou na ferrovia. É por isso que o movimento operário em Porto Alegre teve que administrar tais custos.

A atitude de Borges de Medeiros, simpática a algumas reivindicações operárias, fomentou a criação de um grupo pró-republicano no seio da FORGS. Derradeiro golpe nas posiçôes anarquistas foi desferido em maio de 1918, quando sua diretoria produz um questionário sobre a "atitude" de cada Sindicato "perante a Federação": o Sindicato dos Canteiros recusa-se a respondê-lo e é expulso, o que já fora feito com a União Operária Internacional. Afastados da FORGS, os anarquistas constituíram sua própria organização, a União Geral dos Trabalhadores (UGT), cujos estatutos a transformariam em uma verdadeira "entidade anarco-sindicalista" (Gertz, 1989, p. 126). 
Não foi possível precisar se o principal objetivo dos anarquistas da UGT era tornarem-se lideranças de outra entidade geral de trabalhadores ou, ao contrário, reconquistar posiçōes no interior da FORGS, mas os acontecimentos levaram a essa segunda alternativa. Desde o final de junho de 1918, uma greve de metalúrgicos e têxteis ameaçava generalizar-se, enquanto os pedidos da FORGS a Borges de Medeiros para que solucionasse a carestia não encontravam resultado. A existência de três entidades (UGT, FORGS e União Metalúrgica) obstava a generalização da greve, mesmo porque a Federação não a apoiava. Aparentemente ocorria a mesma situação de um ano antes: um grupo é favorável à Greve Geral e outro é contrário. Tanto em 1917 como em 1918 há conflito de interesses entre grupos organizados do movimento operário, mas, em 1917, o objeto da disputa era a necessidade e viabilidade da convocação de uma Greve Geral e chegou-se a um acordo devido ao chamado "princípio minimax": os contendores teriam interesses em parte compatíveis e em parte incompatíveis. A incompatibilidade dizia respeito aos custos que adviriam à FORGS se a greve fosse reprimida e a entidade fechada. O "princípio minimax" permite que o acordo se estabeleça desde que os contendores admitam ceder um mínimo para não perder um máximo. Ao se criar a Liga de Defesa Popular, chegou-se a um acordo, pois nem a greve deixou de ser convocada, nem os partidários da greve separaram-se da FORGS, nem se punha, em princípio, a Federação em risco. Em 1918, o objeto da disputa não era a Greve Geral, mas a legitimidade da dominação deste ou daquele grupo político concorrente no movimento operário. Não era, portanto, uma disputa solúvel por meio do "princípio minimax", mas do "jogo de soma-zero": onde um dos contendores ganhava, o outro perdia (Aubert, 1972, p. 283-284). Nessa situação, o objetivo dos anarquistas não foi o de conquistar para sua posição (pró-Greve Geral) e, conseqüentemente, para sua organização (UGT) parcelas do movimento operário, mas o de ganhar para sua posição quadros que se oporiam internamente à diretoria da FORGS.

O objetivo foi alcançado em reunião na Federação Operária em 18 de julho. Redigiu-se um memorial que seria enviado a Borges de Medeiros e, antes do final da reunião, a diretoria da FORGS pediria sua exoneração dos cargos "por incompatibilidade com as classes trabalhadoras”. A Greve Geral de 1918 foi reprimida e não obteve nenhuma reivindicação, mas, assim como os anarquistas avaliaram 
1917 como uma derrota, avaliaram 1918 como uma vitória (Gertz, 1989 , p. 125-126). Por certo, a avaliação dos anarquistas sobre "derrotas" e "vitórias" não referia-se mais à conquista de reivindicações, mas à capacidade de dominar esta ou aquela parcela dos trabalhadores organizados.

\section{A pulverização das correntes operárias (1919-1925)}

Há poucas informações sistemáticas sobre o movimento operário no Rio Grande do Sul ao longo da década de 1920, mas há indícios de que, inicialmente, ocorreu a pulverização das correntes políticas e que, após, estas se reorganizaram em blocos.

A reunião dos grupos pró-PRR e apartidário não significou a paz interna do movimento operário, mesmo porque a atitude do governo estadual em 1919 foi diferente daquela tomada em 1917. Como em 1918, a polícia estadual invadiu sedes operárias e prendeu lideranças; houve tiroteios entre tropas e grevistas. Além disso, a Liga de Defesa Popular e a FORGS, em conjunto, lideraram as mobilizações em 1917 , ao contrário de 1919, quando os trabalhadores dos transportes públicos e telefonia, mesmo em greve, mantinham-se alheados da Federação.

O grupo apartidário que reconquistou o controle da FORGS viase enfraquecido com a emergência de outros grupos. Surgiu em Porto Alegre um grupo pró-soviético (União Maximalista), que denunciava o acordo dos sindicalistas com o grupo pró-PRR. Aparentemente, o grupo pró-PRR julgou que não valia a pena confrontar-se com o governo do estado depois da greve de 1919 , porque há registro de dois sindicatos de gráficos, a União Tipográfica e o Sindicato Gráfico Comunista (Correio do Povo, 8 set. e 8 dez. 1921). Houve quem fizesse comícios em prol de um "Partido Sindicalista Parlamentar" em 1920 e, em 1925, surge um "Partido Trabalhista" (Thaddeu, 1981, p. 9; Diário de Notícias, 24 mar. e 21 nov. 1925). Nenhum desses intentos, nem mesmo a Liga dos Operários Republicanos de 1924, poderia ser considerado inautêntico, porque todos contam em seus quadros com militantes oriundos do movimento operário da década de 1910 (A Federação, 16 jan. e 25 mar. 1924).

Os anarquistas e sindicalistas, apesar de expandirem sua influência ao interior do Rio Grande do Sul, promovem um congresso em 1920 
que, longe de reconsolidar o sindicalismo, expõe as fissuras que estavam ocorrendo no movimento operário, fissuras talvez agravadas com o alinhamento da Federação Operária com os anarquistas em nível internacional. Com efeito, em 1925, a FORGS nomeou a Federación Obrera Regional Argentina (anarquista) como sua representante no Congresso da Associação Internacional dos Trabalhadores (Rodrigues, 1979 , p. 48-49 e 56).

As eleições estaduais de 1922 e a Revolução Assisista de 1923 tenderam a, mais uma vez, reorganizar os blocos operários. Há manifestos operários contra e a favor dos candidatos Borges de Medeiros e Assis Brasil. Os sindicalistas suspendem o funcionamento de alguns sindicatos para evitar que sua atividade fosse apropriada por alguma das correntes em guerra civil. A Liga dos Operários Republicanos, criada em 1924, alinha desde Francisco Xavier da Costa até sindicalistas de 1917 e 1919. Também em Santa Maria, em fevereiro de 1924, criava-se um Centro Republicano Operário (Bak, 1996, p. 42). Os comunistas, que participaram da fundação do PC do B em 1922, também mantêm colunas nos jornais do PRR e da Liga dos Operários Republicanos (v. Rodrigues, [1980], p. 189-190; Gertz, 1990, p. 614; A Evolução, 30 nov. 1925). Não há registros de continuidade na organização de trabalhadores federalistas, mas em 1925, por ocasião da candidatura pelo PRR do militar que deu ordens para a tropa atirar contra grevistas em 1919, se estabelece uma nova polêmica, agora entre a FORGS e a Liga dos Operários Republicanos. Estes últimos criticam a FORGS por se manter como uma "vestal", guardando princípios de neutralidade política. O interessante da polêmica é que os operários republicanos não deixam de se assumir como "sindicalistas", isto é partidários de que a organização operária seja feita na forma de sindicatos, politicamente neutros (Petersen \& Lucas, 1992, p. 296-303).

\section{À guisa de conclusão}

Poderíamos estender a enumeração de indícios de bipolaridade política no movimento operário o quanto quiséssemos. Com efeito, as "Frentes Sindicalistas" da década de 1930 e seu combate aos Círculos Operários e aos comunistas carregam consigo a tradição do sindicalismo apartidário. Até mesmo a fundação do PTB, em 1945, traz à 
tona nomes de militantes da Federação Operária, com especial destaque para o alfaiate Vigo Collin, que depois de 1917 alinha-se com o PRR, a ponto de tornar-se conselheiro municipal em 1924, ocupando o cargo que antes pertencia a Xavier da Costa (Silva Jr., 1994, p. 400; Bodea, 1992 , p. 22). Isso, no entanto, serviria apenas para um alargamento ensaístico do universo empírico da interpretação que pretendi demonstrar: que, mais do que ideários operários ou socialistas europeus, no Rio Grande do Sul, são os caminhos da política estadual que se constituem como referências das opçóes políticas dos trabalhadores organizados.

\section{Bibliografia e fontes citadas}

A Democracia, Porto Alegre, 1905-1907.

A Evolução, 30 nov. 1925.

A Federação, 16 jan. e 25 mar. 1924 (NPH 370-E).

[A] Gazetinha, Porto Alegre, 1892-1898.

A Luta, Porto Alegre, 1906-1911.

A Voz do Trabalhador, Rio de Janeiro, 1908-1909, 1913-1915.

BAK, Joan Lamaysou. Labor, community and the making of a cross-class alliance in Brazil: the 1917 railroad strikes in Rio Grande do Sul. [Artigo inédito, 1996].

BAK, Joan Lamaysou. Regional perspectives on Brazilian labor history: labor, state and ideology in Rio Grande do Sul, 1889-1917. Paper apresentado na Latin American Labor Conference, abril de 1994.

BATALHA, Cláudio Henrique de Moraes. Uma outra consciência de classe? O sindicalismo reformista na Primeira República. Ciências Sociais Hoje, 1990. São Paulo: Vértice, 1990, p. 117-127.

BODEA, Miguel. Trabalhismo e populismo no Rio Grande do Sul. Porto Alegre : Ed. da Universidade-UFRGS, 1992.

Correio do Povo, 8 set. e 8 dez. 1921 (NPH 376-E).

Diário de Notícias, Porto Alegre, 24 mar. e 21 nov. 1925 (NPH 320-E).

Diário Popular, Pelotas, 1917.

Echo do Povo, Porto Alegre, 1908-1914.

Echo Operário, Rio Grande, 1896-1899.

FRANCO, Sérgio da Costa. Júlio de Castilhos e sua época. 2. ed., Porto Alegre : Ed. da Universidade-UFRGS, 1988.

GERTZ, René E. (ed.). Memórias de um imigrante anarquista (Friedrich Kniestedt). Porto Alegre : EST, 1989.

GERTZ, René E. Um jornal anarquista em Porto Alegre: Der Freie Arbeiter. Veritas. Porto Alegre, PUCRS, v. 35, n. 140, dez. 1990, p. 606-617.

GOMES, Ângela de Castro. Burguesia e trabalho. Política e legislaçāo social no Brasil 1917-1937. Rio de Janeiro: Campus, 1979.

O Diário, Porto Alegre, 1912-1917. 
O Exemplo, Porto Alegre, 1908-1911.

O Rebate, Pelotas, 1917.

Opinião Pública, Pelotas, 1917.

PETERSEN, Silvia Regina Ferraz \& LUCAS, Maria Elizabeth. Antologia do movimento operário gaúcho (1870-1937). Porto Alegre : Ed. da UniversidadeUFRGS/Tchê!, 1992.

PETERSEN, Silvia Regina Ferraz. As greves no Rio Grande do Sul (1890-1919). In: DACANAL, José Hildebrando \& GONZAGA, Sergius (orgs.). RS: Economia e política. Porto Alegre : Mercado Aberto, 1979, p. 277-327.

PETERSEN, Silvia Regina Ferraz. Guia para o estudo da imprensa periódica dos trabalhadores do Rio Grande do Sul: 1874-1940. Porto Alegre : FAPERGS/Ed. da Universidade-UFRGS, 1989.

PINHEIRO, Paulo Sérgio \& HALL, Michael. A classe operária no Brasil 1889-1930. Documentos. São Paulo: Alfa-Omega, 1979.

RODRIGUES, Edgar. Alvorada Operária. Rio de Janeiro : Mundo Livre, 1979.

RODRIGUES, Edgar. Novos rumos. Pesquisa social, 1922-1946. Rio de Janeiro : Mundo Livre, [1980].

RÜDIGER, Francisco Ricardo. O proletariado gaúcho e a Revoluçāo Federalista. Estudos Ibero-Americanos. Porto Alegre, PUCRS, v. XVII, n. 1, jul. 1991, p. $37-$ 46.

SILVA Jr., Adhemar Lourenço da. "Povo! Trabalhadores!": tumultos e movimento operário. (Estudo centrado em Porto Alegre, 1917). Porto Alegre, dissertação de mestrado em História-UFRGS, 1994.

SILVA Jr., Adhemar Lourenço da. A Confederação Operária Brasileira e o Rio Grande do Sul (1913-1915). Logos, Canoas, v.7, n. 1, 1. sem. 1995a, p. 45-54.

SILVA Jr., Adhemar Lourenço da. Contribuiçāo a uma história dos de baixo do sindicalismo. Estudos Ibero-americanos, Porto Alegre, v. XXI, n. 1, jul. 1995b, p. 6183.

SILVA Jr., Adhemar Lourenço da. Organizaçāo e lutas dos trabalhadores em pedra no Rio Grande do Sul (1906-1917). Porto Alegre, Relatório de pesquisaFAPERGS, 1996a.

SILVA Jr., Adhemar Lourenço da. A Greve geral de 1917 em Porto Alegre. Anos 90, Porto Alegre, n. 5, jul. 1996b, p. 183-205.

SOUZA, Newton Stadler. $O$ anarquismo na Colônia Cecília. Rio de Janeiro : Civilização Brasileira, 1970.

THADDEU, Vera Lúcia Trommer. Transcrição das notícias compiladas no Correio do Povo no período 1920-1923 sobre a organização do operariado rio-grandense. Trabalho de Graduaçāo em História-UFRGS, 1981.

TRINDADE, Hélgio. Aspectos políticos do sistema partidário republicano riograndense. In: DACANAL, José Hildebrando \& GONZAGA, Sergius (orgs.). RS: Economia e política. Porto Alegre : Mercado Aberto, 1979, p. 119-191.

XERRI, Eliana Gasparini. Uma incursão ao movimento operário de Rio Grande no início do século $X X$. Porto Alegre, dissertação de mestrado em História do BrasilPUCRS, 1996. 